\title{
Combined use of expression and CGH arrays pinpoints novel candidate genes in Ewing sarcoma family of tumors Suvi Savola*1,2, Arto Klami ${ }^{3}$, Abhishek Tripathi ${ }^{3}$, Tarja Niini1,2, Massimo Serra ${ }^{4}$, Piero Picci ${ }^{4}$, Samuel Kaski ${ }^{3}$, Diana Zambelli ${ }^{4}$, Katia Scotlandi ${ }^{4}$ and Sakari Knuutila ${ }^{1,2}$
}

Address: ${ }^{1}$ Department of Pathology, Haartman Institute and HUSLAB, University of Helsinki, Helsinki, Finland, ${ }^{2}$ Helsinki University Central Hospital, Helsinki, Finland, ${ }^{3}$ Department of Information and Computer Science, Helsinki University of Technology, Espoo, Finland and ${ }^{4}$ Laboratorio di Ricerca Oncologica, Istituti Ortopedici Rizzoli, Bologna, Italy

Email: Suvi Savola* - suvi.savola@helsinki.fi; Arto Klami - arto.klami@hut.fi; Abhishek Tripathi - abhishek@cis.hut.fi;

Tarja Niini - tarja.niini@helsinki.fi; Massimo Serra - massimo.serra@ior.it; Piero Picci - piero.picci@ior.it; Samuel Kaski - samuel.kaski@hut.fi; Diana Zambelli - diana.zambelli@ior.it; Katia Scotlandi - katia.scotlandi@ior.it; Sakari Knuutila - sakari.knuutila@helsinki.fi

* Corresponding author

Published: 14 January 2009

BMC Cancer 2009, 9:17 doi:10.1186/147/-2407-9-17
Received: I August 2008

Accepted: 14 January 2009

This article is available from: http://www.biomedcentral.com/147I-2407/9/17

(C) 2009 Savola et al; licensee BioMed Central Ltd.

This is an Open Access article distributed under the terms of the Creative Commons Attribution License (http://creativecommons.org/licenses/by/2.0), which permits unrestricted use, distribution, and reproduction in any medium, provided the original work is properly cited.

\begin{abstract}
Background: Ewing sarcoma family of tumors (ESFT), characterized by $t(I I ; 22)(q 24 ; q \mid 2)$, is one of the most common tumors of bone in children and young adults. In addition to EWS/FLII gene fusion, copy number changes are known to be significant for the underlying neoplastic development of ESFT and for patient outcome. Our genome-wide high-resolution analysis aspired to pinpoint genomic regions of highest interest and possible target genes in these areas.

Methods: Array comparative genomic hybridization (CGH) and expression arrays were used to screen for copy number alterations and expression changes in ESFT patient samples. A total of 3 I ESFT samples were analyzed by aCGH and in 16 patients DNA and RNA level data, created by expression arrays, was integrated. Time of the follow-up of these patients was 5-192 months. Clinical outcome was statistically evaluated by Kaplan-Meier/ Logrank methods and RT-PCR was applied on 42 patient samples to study the gene of the highest interest.

Results: Copy number changes were detected in $87 \%$ of the cases. The most recurrent copy number changes were gains at Iq, 2, 8, and I2, and losses at 9p and 16q. Cumulative event free survival (ESFT) and overall survival (OS) were significantly better $(P<0.05)$ for primary tumors with three or less copy number changes than for tumors with higher number of copy number aberrations. In three samples copy number imbalances were detected in chromosomes II and 22 affecting the $F L I I$ and EWSRI loci, suggesting that an unbalanced $t(I I ; 22)$ and subsequent duplication of the derivative chromosome harboring fusion gene is a common event in ESFT. Further, amplifications on chromosomes 20 and 22 seen in one patient sample suggest a novel translocation type between EWSRI and an unidentified fusion partner at 20q. In total 20 novel ESFT associated putative oncogenes and tumor suppressor genes were found in the integration analysis of array CGH and expression data. Quantitative RT-PCR to study the expression levels of the most interesting gene, HDGF, confirmed that its expression was higher than in control samples. However, no association between HDGF expression and patient survival was observed.
\end{abstract}

Conclusion: We conclude that array $\mathrm{CGH}$ and integration analysis proved to be effective methods to identify chromosome regions and novel target genes involved in the tumorigenesis of ESFT. 


\section{Background}

The Ewing sarcoma family of tumors (ESFT) is a group of highly aggressive and often metastatic small round cell tumors characterized by specific $t(11 ; 22)$ (q24;q12) chromosomal rearrangements, which create the EWS/FLI1 gene fusion and thereby a chimeric, oncogenic transcription factor [1]. ESFT is one of the most common bone and soft tissue tumors in children and young adults arising generally during the second decade of life $[2,3]$. The ESFT tumors are divided into four subtypes according to the histopathological description: classical Ewing sarcoma in bones, extraskeletal Ewing sarcoma, peripheral neuroepithelioma (PNET), and Askin's tumor. Most of these ESFT cases manifest defects in the maintenance of genomic stability with subsequent DNA copy number alterations.

Conventional CGH and array CGH studies have shown that $63-84 \%$ of ESFT patient samples have copy number changes [4-9]. These copy number alterations play a significant role in the tumorigenesis and malignant progression of solid tumors. The diagnosis and clinical management of patients would substantially benefit from identification of these novel chromosomal targets and molecular markers involved in the tumorigenesis of ESFT, since secondary genetic alterations in ESFT have been shown to correlate with patient's outcome. In addition to overall number of chromosomal imbalances $[10,11]$, gains of 1q, 8 and 12 and losses of 9p21.3 and 16q have been associated with poor clinical outcome [7,12-14]. Rapid development of microarray technology has led to more sophisticated analyses, which can be utilized to find novel tumor specific genetic alterations. Further, numerous studies have demonstrated that integrating genomic data from different sources, e.g. at RNA and DNA level, can enhance the reliability of genetic analysis in understanding tumor progression. Our aim was to identify common regions of gain and loss and to define the influence of copy number alterations on gene expression to identify chromosomal areas and genes involved in malignant progression of Ewing sarcoma. We used high-resolution array-based CGH to screen simultaneously multiple loci for possible copy number imbalances in ESFT patient samples. This approach enables us to detect both largescale and gene-size copy number alterations down to 35 $\mathrm{kb}$ in size. To investigate the impact of copy number imbalances on the gene expression levels of affected genes, we performed also an expression array analysis to combine RNA and DNA level data and validated the most interesting result by quantitative RT-PCR analysis.

\section{Methods}

Patient samples and clinical data

Fresh frozen samples (stored at $-70^{\circ} \mathrm{C}$ ) were collected from the archives of the Laboratory of Oncologic Research, Istituti Ortopedici Rizzoli (IOR), Bologna. A total of 31 tumor specimens of from ESFT patients treated at IOR between years 1992 and 2005 were available for the aCGH study. In order to study ESFT expression profiles, 42 patient samples were collected for RNA extraction. To validate the ESFT diagnosis, the presence of EWS/ FLI or EWS/ERG translocation was confirmed by RT-PCR for all samples with available RNA. Clinical data for 31 samples (Table 1) used in aCGH and in data integration analysis were collected from the patient records at IOR. All patients were treated within controlled prospective trials $[15,16]$. The mean age of the patients was 20.7 years, ranging from 5 to 41 years and the male-to-female ratio was 22:9 (2.4). Of the 31 samples used in aCGH analysis, 23 were primary tumors, two recurrencies, and six metastatic tumors. The majority of these patients $(22 / 31)$ were diagnosed with classical Ewing sarcoma, four with soft tissue Ewing sarcoma, three with Askin's tumor and two with PNET. Seven of the patients with primary tumors had metastases at the time of diagnosis. Sixteen tumors had Type 1 (exon 7 of EWS/exon 6 of FLI1) gene fusion, eight had other types of fusion (Type 2: exon 7 of EWS/exon 5 of FLI1 or Type 3: exon 10 of EWS/exon 6 of FLI1), three samples were negative for the most common fusion genes (EWS-FLI1 and EWS-ERG), and in four cases this information was not available. The sample set was handled in a coded fashion and the collected clinical and quality control data of the samples is publicly available in a microarray database at http://www.cangem.org[17]. This study has been reviewed and approved by the Ethical Review Board of Helsinki University Central Hospital.

\section{Nucleic acid isolation}

Genomic DNA from 31 samples was extracted using the standard phenol-chloroform method. Prior to extraction, the proportion of tumor cells was verified to exceed $75 \%$ in all samples by using hematoxylin and eosin-stained sections. Tissue necrosis was evaluated on the whole tumor mass. In cases with high percentages of necrosis, nucleic acids were isolated from the tissue samples in which viable cells were still present. Reference DNAs, male and female, were extracted from pooled blood samples (4 individuals) obtained from Blood Service, Red Cross, Finland. RNA from 42 ESFT samples was isolated using a TRIzol extraction kit (Invitrogen Ltd., Paisley, UK) according to the manufacturer's instructions. Both high quality genomic DNA and RNA were available for 16 patients after the nucleic acid extraction instead of 42 patients, due to insufficient amount of starting material. DNA and RNA concentrations were measured using a GeneQuant pro spectrophotometer (Amersham Pharmacia, Cambridge, UK), and RNA quality was assessed using Agilent's 2100 Bioanalyzer (Agilent, Palo Alto, CA). 


\begin{tabular}{|c|c|c|c|c|c|c|c|c|c|c|c|c|c|c|c|}
\hline Code & $\begin{array}{c}\text { Included in } \\
\text { data } \\
\text { integration } \\
\text { analysis }\end{array}$ & Diagnosis & $\begin{array}{c}\text { Origin } \\
\text { of sample }\end{array}$ & $\begin{array}{l}\text { Chemotherapy } \\
\text { or radiation } \\
\text { before sample } \\
\text { collection }\end{array}$ & $\underset{\text { from }}{\text { Material }}$ & Necrosis & $\begin{array}{l}\text { Patient Status } \\
\text { at Diagnosis }\end{array}$ & Age & Sex & Location & $\begin{array}{c}\text { Outcome } \\
\text { EFS }\end{array}$ & $\begin{array}{c}\text { EFS } \\
\text { months }\end{array}$ & $\begin{array}{c}\text { Outcome } \\
\text { OVs }\end{array}$ & $\begin{array}{c}\text { OVS } \\
\text { months }\end{array}$ & $\begin{array}{c}\text { Type of } \\
\text { Translocation }\end{array}$ \\
\hline DI50 & $x$ & Ewing & PRI & no & Biopsy & & Localized & 23 & $M$ & Femur & REL & 6 & DEAD & 12 & $\begin{array}{c}\text { EWS/FLI-I } \\
\text { type 2 }\end{array}$ \\
\hline D152 & $x$ & Ewing & PRI & no & Biopsy & & Pri Met Lung & 15 & M & Pelvis & REL & 8 & DEAD & 17 & $\begin{array}{l}\text { EWS/FLI-I } \\
\text { type } 2\end{array}$ \\
\hline DI53 & $x$ & Ewing & PRI & no & Biopsy & & Pri Met Bone & 22 & M & Pelvis & REL & 0 & DEAD & 5 & $\begin{array}{l}\text { EWS/FLI-I } \\
\text { type } 3\end{array}$ \\
\hline DI54 & $x$ & Ewing & PRI & yes & Resection & $50 \%$ & Localized & 19 & M & Humerus & REL & 19 & AWD & 57 & $\mathrm{Neg} / \mathrm{Neg}$ \\
\hline D155 & & Ewing & PRI & no & Biopsy & & Localized & 15 & $\mathrm{~F}$ & Pelvis & NED & 69 & NED & 69 & $\begin{array}{c}\text { EWS/FLI-I } \\
\text { type I }\end{array}$ \\
\hline D162 & & Ewing & PRI & yes & Resection & $90 \%$ & Localized & 20 & M & Tibia & NED & 61 & NED & 61 & $\mathrm{Neg} / \mathrm{Neg}$ \\
\hline D239 & & Ewing & PRI & yes & Resection & $95 \%$ & Localized & 21 & $\mathrm{~F}$ & Scapula & REL & 34 & NED & 41 & $\begin{array}{l}\text { EWS/FLI-I } \\
\text { type } 2\end{array}$ \\
\hline D240 & & Ewing & PRI & yes & Resection & $30 \%$ & Pri Met Lung & 10 & $\mathrm{~F}$ & Humerus & REL & 13 & DEAD & 15 & $\begin{array}{l}\text { EWS/FLI-I } \\
\text { type I }\end{array}$ \\
\hline D24I & & Ewing & PRI & yes & Resection & $>95 \%$ & Localized & 28 & M & Femur & NED & 47 & NED & 47 & $\begin{array}{c}\text { EWS/FLI-I } \\
\text { type } 2\end{array}$ \\
\hline D245 & & Ewing & PRI & yes & Resection & $70 \%$ & Localized & 22 & M & Radius & REL & 4 & DEAD & 8 & NA \\
\hline D248 & & Ewing & PRI & yes & Resection & $95 \%$ & Localized & 11 & $M$ & Scapula & NED & 76 & NED & 76 & $\begin{array}{c}\text { EWS/FLI-I } \\
\text { type I }\end{array}$ \\
\hline D3II & $x$ & Ewing & PRI & no & Biopsy & & Localized & 13 & $M$ & Pelvis & NED & 43 & NED & 43 & $\begin{array}{c}\text { EWS/FLI-I } \\
\text { type I }\end{array}$ \\
\hline $\mathrm{D} 313$ & $x$ & Ewing & PRI & no & Biopsy & & Localized & 24 & $M$ & Femur & REL & 18 & NED & 117 & $\begin{array}{c}\text { EWS/FLI-I } \\
\text { type I }\end{array}$ \\
\hline D316 & $x$ & Ewing & PRI & yes & Resection & $60 \%$ & Pri Met Lung & 11 & M & Femur & REL & 10 & DEAD & 10 & $\begin{array}{c}\text { EWS/FLI-I } \\
\text { type I }\end{array}$ \\
\hline D320 & $x$ & Ewing & PRI & no & Biopsy & & Localized & 5 & M & Humerus & REL & 14 & DEAD & 21 & $\begin{array}{c}\text { EWS/FLI-I } \\
\text { type } 2\end{array}$ \\
\hline D322 & $x$ & Ewing & PRI & yes & Resection & $25 \%$ & Localized & 27 & $\mathrm{~F}$ & Femur & REL & 29 & NED & 67 & $\begin{array}{l}\text { EWS/FLI-I } \\
\text { type I }\end{array}$ \\
\hline D242 & & Ewing Extr & PRI & no & Biopsy & & Localized & 41 & $\mathrm{~F}$ & Thorax & NED & 56 & NED & 56 & NA \\
\hline D246 & & Ewing Extr & PRI & no & Biopsy & & Localized & 26 & $\mathrm{~F}$ & Thigh & NED & 49 & NED & 49 & $\begin{array}{c}\text { EWS/FLI-I } \\
\text { type I }\end{array}$ \\
\hline D249 & & Ewing Extr & PRI & no & Biopsy & & Localized & 35 & M & Thigh & REL & 7 & AWD & 13 & NA \\
\hline D252 & & Ewing Extr & PRI & no & Biopsy & & Pri Met Lung & 18 & M & Thigh & REL & 0 & DEAD & 13 & $\begin{array}{c}\text { EWS/FLI-I } \\
\text { type I }\end{array}$ \\
\hline D253 & & Askin's & PRI & yes & Resection & $10 \%$ & Localized & 24 & M & Rib & REL & 5 & DEAD & 12 & $\begin{array}{c}\text { EWS/FLI-I } \\
\text { type } 2\end{array}$ \\
\hline D254 & & Askin's & PRI & yes & Resection & $15 \%$ & Pri Met Lung & 21 & M & Rib & NA & NA & NA & NA & NA \\
\hline DI56 & & Askin's & REC & no & Resection & & Localized & 15 & M & Rib & REL & 17 & DEAD & 21 & $\begin{array}{l}\text { EWS/FLI-I } \\
\text { type I }\end{array}$ \\
\hline D157 & $x$ & Ewing & REC & no & Amputation & & Pri Met Lung & 30 & $\mathrm{~F}$ & Femur & REL & 3 & DEAD & 25 & $\begin{array}{c}\text { EWS/FLI-I } \\
\text { type I }\end{array}$ \\
\hline D255 & $x$ & Ewing & LUNG MET & no & Resection & & Pri Met Lung & 17 & M & Scapula & REL & 31 & DEAD & 43 & $\begin{array}{c}\text { EWS/FLI-I } \\
\text { type I }\end{array}$ \\
\hline D32I & $x$ & Ewing & LUNG MET & no & Lobectomy & & Localized & 24 & M & Pelvis & REL & 34 & DEAD & 80 & $\begin{array}{c}\text { EWS/FLI-I } \\
\text { type I }\end{array}$ \\
\hline D315 & $x$ & PNET & BONE MET & no & Biopsy & & Localized & 16 & $M$ & Tibia & REL & 58 & DEAD & 99 & $\begin{array}{c}\text { EWS/FLI-I } \\
\text { type I }\end{array}$ \\
\hline D257 & $x$ & PNET & BONE MET & no & Biopsy & & Localized & 16 & $\mathrm{~F}$ & Femur & REL & 6 & DEAD & 8 & $\begin{array}{c}\text { EWS/FLI-I } \\
\text { type 2 }\end{array}$ \\
\hline
\end{tabular}

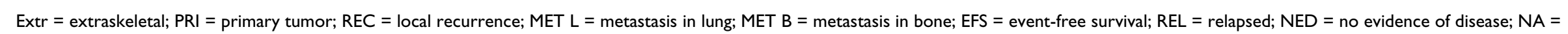
not available; OVS = overall survival; $A W D=$ alive with disease. 


\section{Array CGH hybridization, microarray image and data analysis}

Digestion, labeling, hybridization, and data analysis of genomic DNA was performed according to Agilent's protocol version 2.0 for $44 \mathrm{~K}$ arrays as described previously $[18,19]$. In brief, the sample and reference DNAs, $7 \mu \mathrm{g}$ each, were fragmented and 1.0-1.5 $\mu \mathrm{g}$ of the fragmented DNA was labeled by random priming using a BioPrime array labeling kit (Invitrogen, Carlsbad, CA) with Cy3dUTP and Cy5-dUTP dyes (Perkin-Elmer, Wellesley, MA). Labeled samples were purified, combined, and hybridized for $48 \mathrm{~h}$ at $65^{\circ} \mathrm{C}, 10 \mathrm{rpm}$ to Human Genome CGH 44B oligomicroarray slides (Agilent Technologies Santa Clara, CA) against gender matched reference DNAs. Then the arrays were washed and scanned [18]. The array images were analyzed and data was extracted using Agilent's Feature Extraction (FE) Software version 8.1, providing dye normalization (Linear Lowess) and background substraction. The chromosomal imbalances were identified using Agilent's CGH Analytics software version 3.4. The altered chromosomal regions and breakpoints were detected using ADM-2 (threshold 8.0) with 1.0 Mb window size. Patient survival analysis was then performed by KaplanMeier and Logrank (Mantel-Cox) methods considering either event-free or overall survival.

\section{Expression array hybridizations}

The ESFT RNA samples, 42 cases and control samples, a CD34+ cell line and a pool of normal muscle tissue samples were hybridized to Affymetrix Human Genome U133 Plus 2.0 oligonucleotide microarrays (Affymetrix, Santa Clara, CA) according to the manufacturer's GeneChip ${ }^{\circledR}$ One-Cycle Target Labeling-protocol. In brief, $5 \mu \mathrm{g}$ of total RNA was reverse transcribed to cDNA using One-Cycle cDNA Synthesis Kit (Affymetrix). Biotin-labeling of antisense cRNA was carried out using IVT Labeling Kit (Affymetrix). The labeled and fragmented cRNA (15 $\mu \mathrm{g}$ of each) was hybridized for $16 \mathrm{~h}$ at $45^{\circ} \mathrm{C}$ in a hybridization oven 640 (60 rpm). Washing and staining of the arrays with streptavidin-phycoerythin (SAPE) was completed in a Fluidics Station 450 (Affymetrix). The arrays were then scanned using a confocal laser GeneChip Scanner 3000 and images were analyzed using GeneChip Operating Software (GCOS; Affymetrix, Sacramento, CA). The expression measurements were preprocessed using Robust Multi-array Analysis (RMA) for the whole collection of 44 chips (42 ESFT patients and two hypothetical normal samples). While only 16 of these were used in the integration, running the preprocessing for the whole collection $(n=44)$ provides more accurate estimates of the true expression levels.

\section{Integration of gene copy number and expression data}

In order to compare the measurements obtained on Affymetrix and Agilent platforms, the sequences used in the probes were matched to the NCBI36 human genome build, using the BLAST algorithm to provide a unique location for each Affymetrix probe set using the target sequences provided by Affymetrix and each Agilent probe. Multiple matches were combined to provide a single location covering all matches if the resulting sequence length was below 2,5 Mb. Note that the locations do not necessarily match the reference sequences of the NCBI36 genome, since they correspond to the locations of the probe sequences, not RefSeqs. In the joint analysis, each Affymetrix probe set was paired with the closest Agilent probe, measured as the distance between the mean points of the sequences. The Affymetrix probe sets that had no Agilent probes within $375 \mathrm{~kb}$ were ignored. Correlation between expression and gene copy number of different patients was measured separately for each gene (identified based on the Affymetrix probe set). Genes with high positive or negative correlation were chosen for further examination. The goal of this process was to detect genes where a copy number change and a change in expression are observed on the same patients. A similar analysis was conducted by first dividing patients into groups according to their copy number status and then testing whether these groups have a significant difference in their expression levels [20]. Here the correlation approach was chosen instead of the testing approach, because it can take into account also small amplification imbalances not detectable with the method described in Section "Array CGH hybridization, microarray image and data analysis". It also takes into account possible higher copy number changes. As a correlation measure we used Spearman's rank correlation, since the copy number data does not follow normal distribution. We used the algorithm of Best [21] to compute the p-value against the correlation being zero, and corrected for multiple testing by computing false discovery rates using the q-value procedure [22]. The correlation was computed only for genes located on chromosome arms where at least $20 \%$ of the full patient collection, including also samples not used in the integration analysis, showed copy number aberration, in order to focus on regions where associations would be likely.

\section{Quantitative RT-PCT analysis by TaqMan Low Density Arrays}

Pre-designed TaqMan PCR probe and primer sets for HDGF were used: Assay ID Hs00610314-m1 (Applied Biosystems, Foster City, CA, USA). All PCRs were done by using ABI PRISM 7900 Sequence Detection System (Applied Biosystems) as recommended by the supplier. Thermal cycling conditions were: $50^{\circ} \mathrm{C}$ for $2 \mathrm{~min}, 95^{\circ} \mathrm{C}$ for $10 \mathrm{~min}, 95^{\circ} \mathrm{C}$ for $15 \mathrm{sec}$ and $60^{\circ} \mathrm{C}$ for $1 \mathrm{~min}$. Gene expression values were calculated based on the $\Delta \Delta \mathrm{Ct}$ method [23], in which RNA from CD34+ cells derived from human bone marrow and pooled muscle normal tissues derived from three patients were the designated cali- 
brators for the analysis of all other samples. CD34+ positive cells and pooled muscle normal tissues were processed in the same way as tumor samples and used as separate calibrators for the RT-PCR experiments. For evaluating the prognostic value of HDGF, we calculated its median expression value, and patients were stratified as "high-expressors" or "low-expressors" relative to the median value. Patient survival analysis was then performed by Kaplan-Meier and Logrank methods considering either event-free survival or overall survival.

\section{Results}

\section{Copy number changes}

Results from a high-resolution analysis of copy number aberrations in ESFT $(n=31)$, using Agilent's 44K oligoarray platform and CGH analytics software are shown in Table 2. In all ESFT patient samples, 0-26 aberrations were detected per sample (mean: 7.2) and 27 of the 31 samples showed (87\%) copy number changes. All samples without copy number changes $(n=4)$ were primary tumors. Metastases (mean: 11.8) showed more copy number changes than local recurrencies (mean: 9.5) and primary tumors (mean: 5.8). The sizes of these aberrations ranged from $<60 \mathrm{~kb}$ deletions to gains or losses of whole chromosomes. Among primary tumors, the samples with low copy number changes $(\leq 3$ copy number aberrations) showed a significantly better prognosis with respect to those with a high number of chromosomal alterations ( $>3$ copy number aberrations), both in terms of event-free and overall survival (Figure 1). Indeed, only $3 / 11$ patients $(27 \%)$ with less than three copy number changes developed metastases within 6 years from diagnosis in contrast with $8 / 10(80 \%)$ of those with a high number of chromosomal alterations $(P=0,03$ Fisher's test), indicating how the number of chromosomal alterations may have a highly prognostic significance despite the low number of patients here considered. Recurrent aberrations were gains of $1 \mathrm{q}(32 \%), 2(29 \%), 8(67 \%)$, and $12(29 \%)$ and losses at $9 \mathrm{p}(23 \%)$ and $16 \mathrm{q}(32 \%)$ as visualized in Figure 2. The prominent deletion in 9p21.3 harboring CDKN2A tumor suppressor gene and microdeletions of these region have been previously described and discussed in a separate report by Savola et al. [18]. The gain of chromosome 8 was the most prominent copy number change in our sample set (21 of 31 cases). Gain of $8 \mathrm{q}$ arm (minimal common overlapping area) was present in all samples with chromosome 8 aberration. The minimal common overlapping area of copy number gain in chromosome 1 was 1q22-qter. In chromosome 12 the smallest common region of gain was 12q13.2-q14.1, which harbors two known oncogenes, ERBB3 and CDK4. Losses of $16 \mathrm{q}$ were observed in three cases together with 1q gain, suggesting the occurrence of an unbalanced $\mathrm{t}(1 ; 16)$. Interesting copy number gains of $11 \mathrm{q} 24.3$-qter and 22q11.12-q12.1 starting or ending, respectively, at
FLI1 and EWSR1 loci, were detected in patient samples D153 (Fig. 3A-D), D248, and D254 (Table 2). Copy number imbalances affecting the same loci were detected also in samples D154 (uncontinuous amplification 22q12.1-q12.1) (Fig. 3F-G), D312 (+11q24.3-qter), and D315 (-22q12.1) (see Table 2). Original microarray data, scanned images and FE output text files, are available at the public repository CanGEM http://www.cangem.org [17].

\section{Integration of gene copy number and expression data}

Array CGH data and expression data were combined for a total of 16 patient samples (Table 1). Matching of expression microarray probes to the corresponding copy number microarray probes using a $375 \mathrm{~kb}$ genomic window yielded 53,145 probe pairs. 10,115 of those located in chromosomal areas where at least $20 \%$ of patients showed a copy number aberration $(1 \mathrm{q}, 2 \mathrm{q}, 8 \mathrm{q}, 12$, and $16 q)$. Several putative ESFT-related genes were pinpointed, differentially expressed due to copy number alteration in these chromosomal locations of highest interest. These novel putative oncogenes and tumor suppressor genes based on our data analysis include 20 genes (by q-value $<0.20$ ), which previously have not been associated with ESFT (Table 3). For a supplementary table with all integration analysis results see Additional file 1.

\section{Microarray analysis and quantitative RT-PCR on HDGF}

Array CGH and expression microarray results on showed clear evidence that patients with HDGF gain had higher HDGF expression (Figure 4A-C, correlation 0.81) than patients without HDGF gain. However, ESFT patients could not be divided unambiguously into two groups (see Figure $4 \mathrm{~A}$ and $4 \mathrm{~B}$ ) based on this data. To validate HDGF microarray results, the relative expression levels of $H D G F$ were analysed by TaqMan Low Density arrays in all 42 available ESFT patient samples (Figure $4 \mathrm{~F}$ ). This analysis confirmed that ESFT patient samples express higher levels of HDGF than normal controls. No statistically significant correlation of HDGF expression with poor clinical outcome could be shown (Figure 4D and 4E), nor correlation with patient gender, age or location could be shown. Clinical data summary of these 42 ESFT patients included in the analysis can be viewed on Additional file 2.

\section{Discussion}

In this study, we have performed a comprehensive genome wide array CGH analysis of 31 EFST patient samples. Our oligoarray CGH results, the recurrent gains of $1 \mathrm{q}, 2,8$, and 12, and losses at $9 \mathrm{p}$ and $16 \mathrm{q}$ that were present in more than $20 \%$ of the patient samples, are in agreement with previous ESFT studies by G-banding, conventional CGH [4-8] and array CGH [9]. Our array CGH results revealed complex large-scale changes in several samples. Gains of DNA sequences were more prevalent 

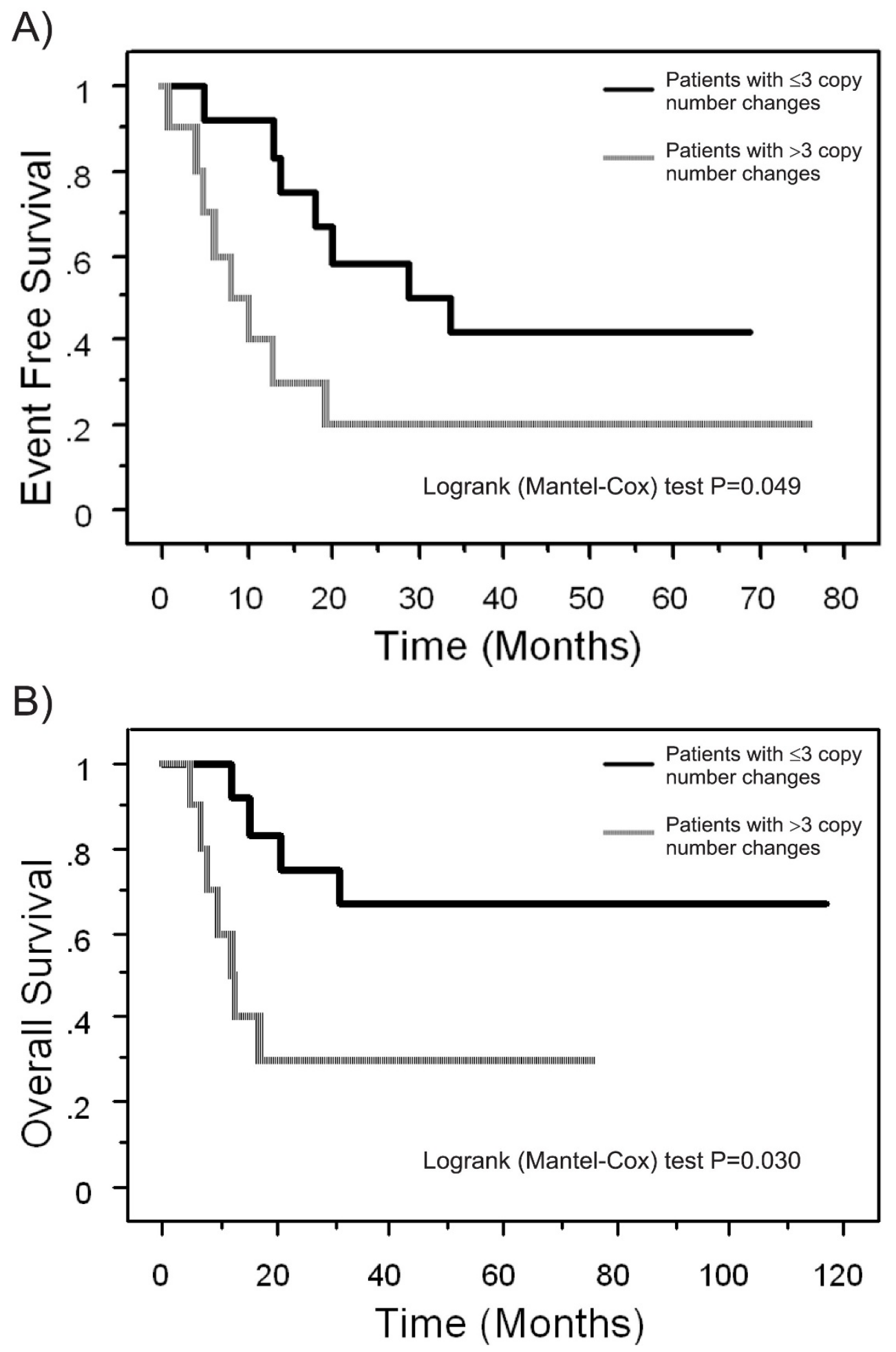

Figure I

Outcome of patients with low copy number changes ( $\leq 3$ copy number aberrations) and high copy number changes ( $>3$ copy number aberrations). Kaplan-Meier plots show $A$ ) event-free survival and $B$ ) overall survival of patients with low copy number changes ( $\leq 3$ copy number aberrations detected in the sample by array $\mathrm{CGH})$ in bold line and with high number copy number changes ( $>3$ copy number aberrations) in hatched line. 

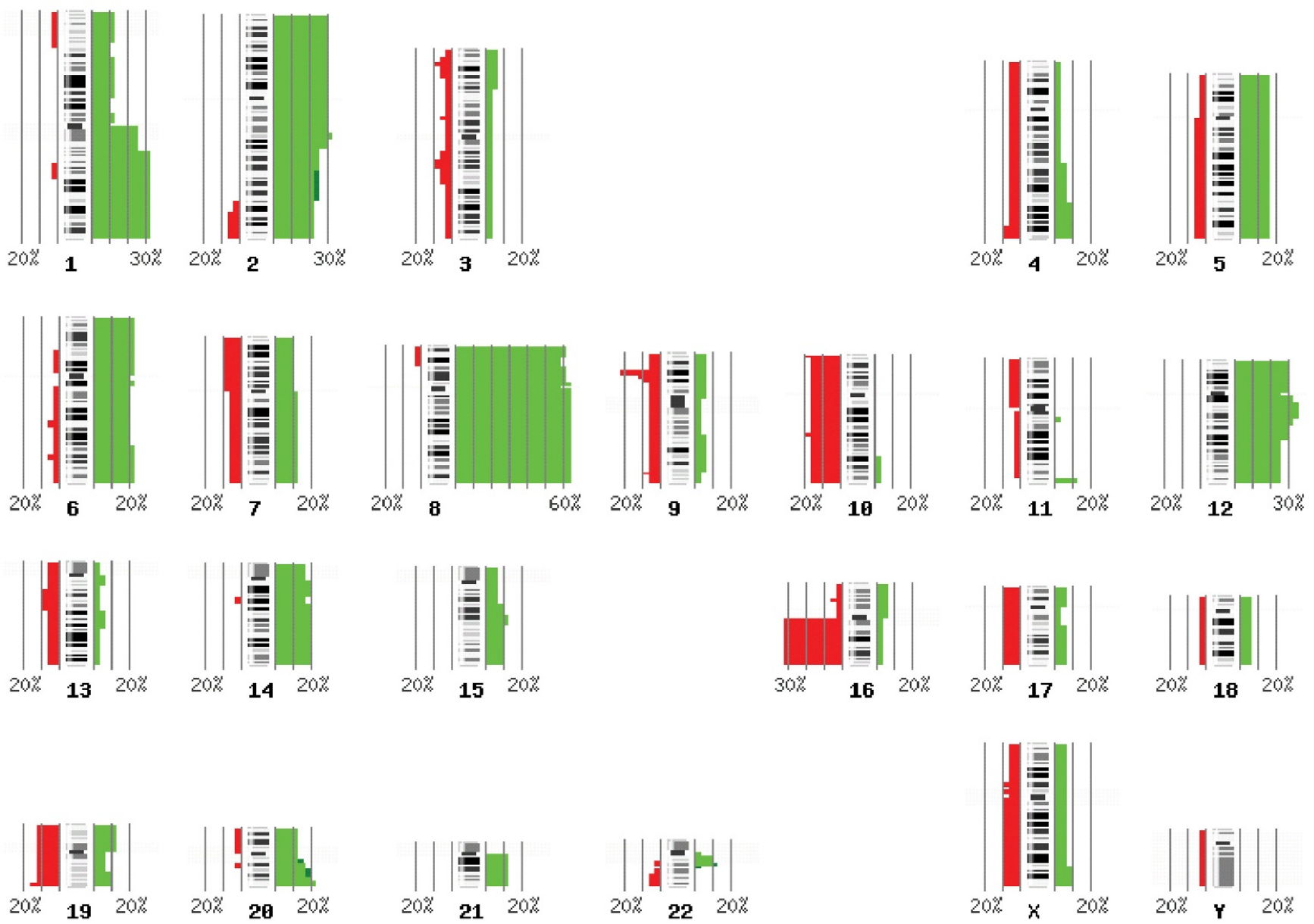

Figure 2

Chromosomal locations of copy number changes in ESFT patient sample $(n=31)$. The ideogram shows the summary of gains and losses of DNA sequence copy numbers and their frequencies in ESFT tissue samples $(n=3 I)$ analyzed by array CGH. Gains (light green) and amplifications (dark green) are shown on the right of each chromosome and losses (red) on the left (number refer to the percentage per band). Chromosomal ideogram was generated using the PROGENETIX software [46].

than losses and most of the gains affected whole chromosomes or chromosome arms. Further, our analysis showed that patients with low copy number changes $(\leq 3$ copy number aberrations) showed a significantly better prognosis than patients with a high number of chromosomal alterations, both in terms of event-free and overall survival.

Concomitant gains of 11q24.3-qter and 22q11.21-q12.1 detected in three samples (D153, D248, and D254) suggest that a reciprocal translocation took place between the EWSR1 and FLI1 loci and thereafter a duplication event of the derivative chromosome 22. Sample D153 had Type 3 EWS-FLI1 translocation and sample D248 Type 1 translocation, which suggests that the possible duplication event of the derivative chromosome is not translocation type- specific. In addition, copy number imbalances affecting the EWSR1 and/or FLI1 loci were detectedin three other samples (D154, D312, and D315). In sample D315, with Type 1 EWS-FLI1 translocation, loss of 22q12.1 was observed to end at the EWSR1 loci. Similar evidence has been reported previously $[12,13,24]$. Our results suggest that duplication of the $\operatorname{der}(22) \mathrm{t}(11 ; 22)$ is a common event in ESFT. Copy number gain of the fusion gene EWSFLI1 may further increase the expression of this fusion product and possibly impair the prognosis. Amplification or gain of a chimeric fusion gene is relatively infrequent mechanism in both leukemia and solid tumors. However, rare cases of gain or amplification of the derivative chromosomes or episomes carrying the fusion gene have been reported [25-27] and gene dosage effect of the fusion gene can improve the tumor growth resulting in more aggres- 
A) D153 Chromosome 11

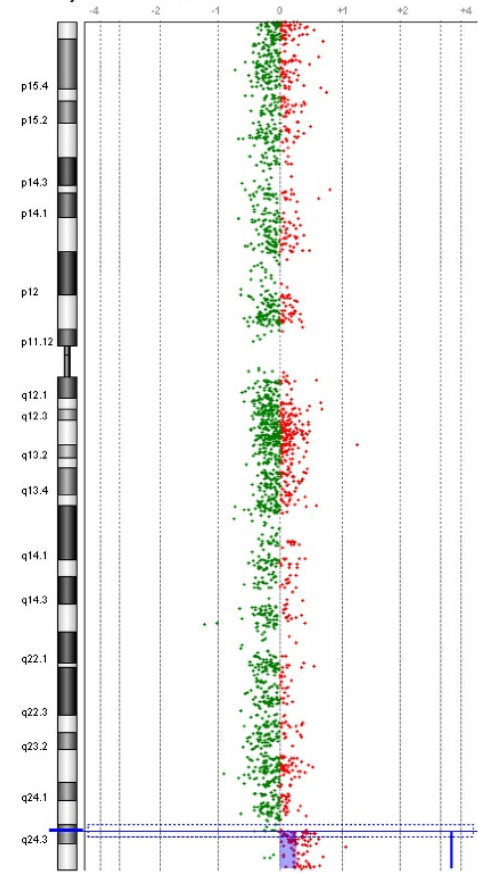

E) D154 Chromosome 20

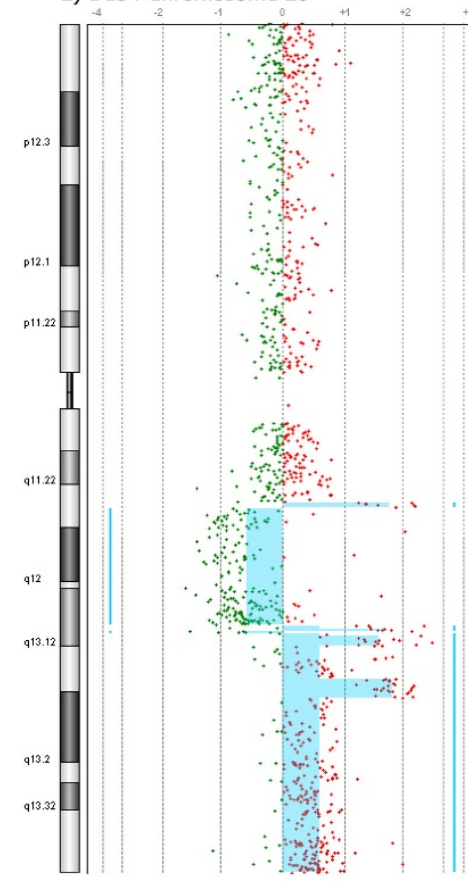

D) D153 Chrom 22 breakpoint of $t(11 ; 22)$

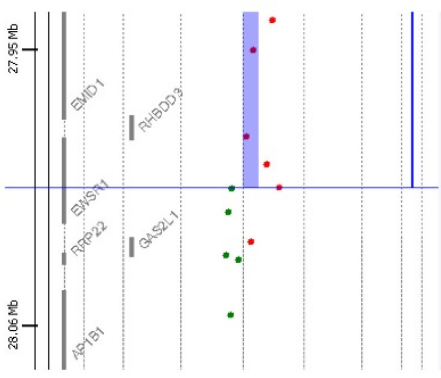

B) D153 Chrom 11 breakpoint of $t(11 ; 22)$

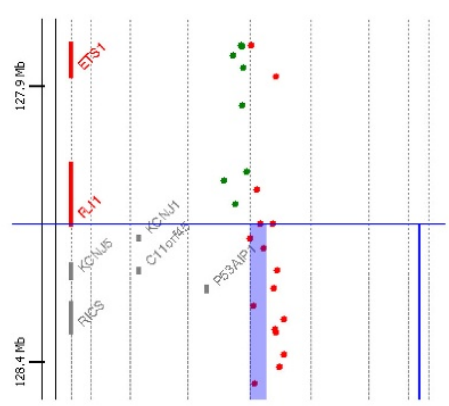

F) D154 Chromosome 22

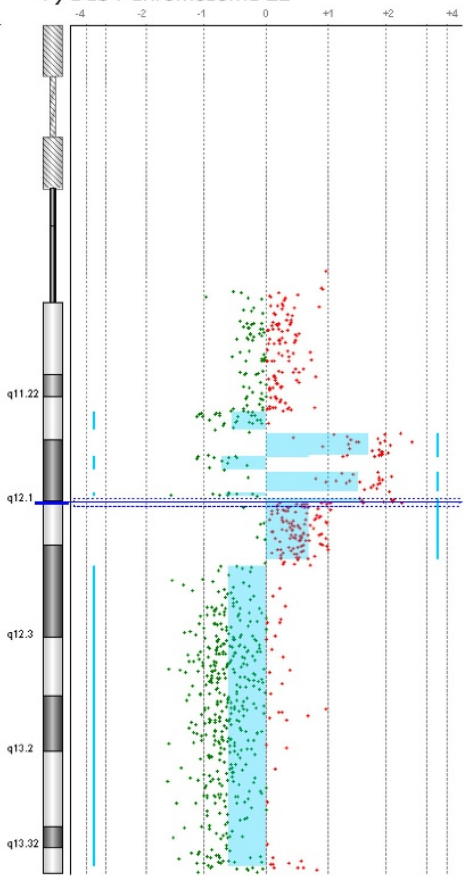

C) D153 Chromosome 22

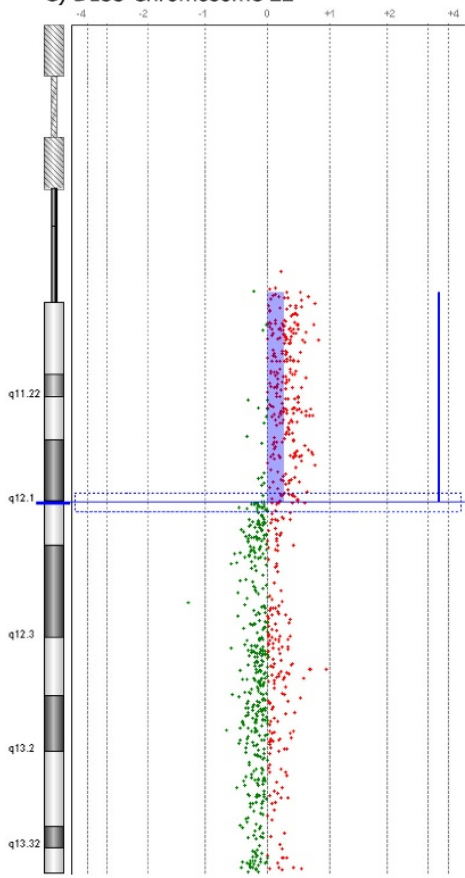

G) D154 copy number transition in EWSR1

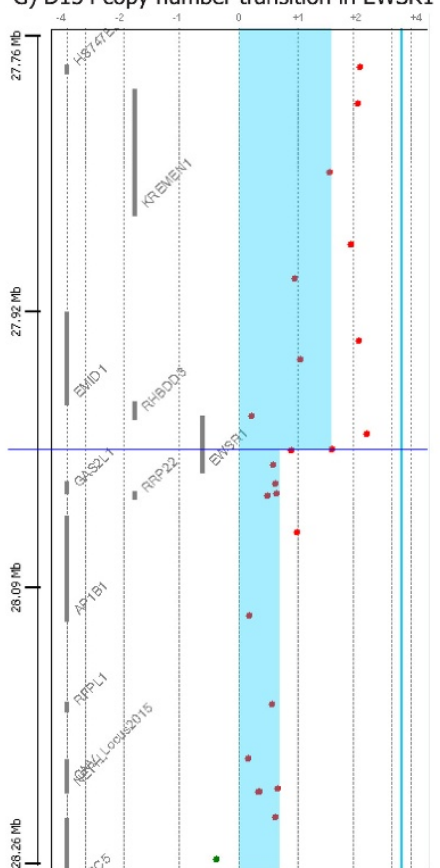

Figure 3

Gain of chromosomal material on chromosomes II and 22 in patient sample DI53 (A-D) and cryptic amplifications on chromosomes 20 and 22 in patient sample DI54 (E-G). A) Chromosome II shows a gain of I I q24.3-qter. B) Breakpoint of copy number gain is inside the FLII locus. Based on aCGH results, the genomic breakpoint location is between I28I480I0-I28I86I80. C) Chromosome 22 shows a gain of 22qII.2I-qI2.I. D) Breakpoint of copy number gain is inside the EWSRI locus. Genomic breakpoint location is between $28007405-28007664$. E) Chromosome 20 shows cryptic

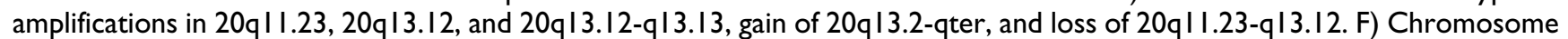

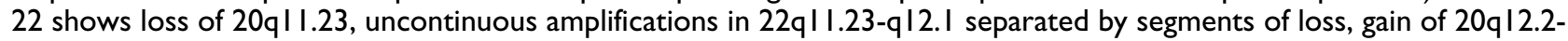
q 12.3 , and loss of $20 \mathrm{q} / 2.3$-qter. G) Copy number transition between amplification and gain in 20qI2.I is in the EWSRI locus. 
Table 2: Array CGH results $(n=31)$ in ESFT patient samples arranged by diagnosis.

\begin{tabular}{|c|c|c|c|c|c|}
\hline Code & Diagnosis & Origin of sample & Array CGH results & Number of changes & $\begin{array}{l}\text { CDKN2A } \\
\text { deletion status }\end{array}$ \\
\hline DI50 & Ewing & PRI & $\begin{array}{l}+1 \mathrm{q},+2,+4,+6,+7,+8,-10,+12,-16 q,+17,-19 \\
+20\end{array}$ & 12 & No deletion 2 \\
\hline DI52 & Ewing & PRI & $+5,+7,+8,+21$ & 4 & No deletion 2 \\
\hline DI53 & Ewing & PRI & $\begin{array}{l}+1,-2 q 35 \text {-qter, }+6,+8,+9 p,-9 q 34.11,-10, \\
+1|q 24.3-q t e r,+12,+16 p,+19,+20 q| 2-q \text { ter, } \\
+22 q|1.21-q| 2.1\end{array}$ & 13 & No deletion 2 \\
\hline DI54 & Ewing & PRI & 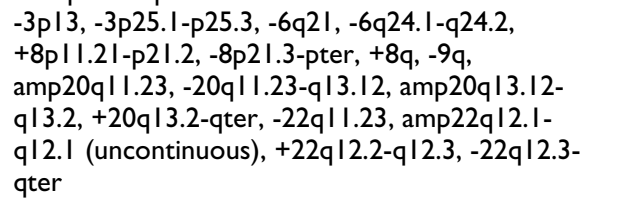 & 16 & No deletion 2 \\
\hline DI55 & Ewing & PRI & No changes detected & 0 & No deletion 2 \\
\hline D162 & Ewing & PRI & $-9 p 21.2-p 21.3$ & 1 & Heterozygous deletion 2 \\
\hline D239 & Ewing & PRI & No changes detected & 0 & No deletion 2 \\
\hline D240 & Ewing & PRI & + Iq22-qter, +12, +Xq26.3-qter & 3 & No deletion 2 \\
\hline D24I & Ewing & PRI & No changes detected & 0 & No deletion 2 \\
\hline D245 & Ewing & PRI & $+4 q 25$-qter, $+5,+8,+|3 q||-q| 2.2$ & 4 & No deletion 2 \\
\hline D248 & Ewing & PRI & $\begin{array}{l}+1,+2 q 21.2-q 33.1, \text { amp } 2 q 31.2-q 33.1,-2 q 33.2-q t e r \\
-4,+8, \text { del } 9 p 21.3,-10,+11 q 24.3-q \text { ter, }+12,+14,- \\
16 p 12.3,-16 q,+17 p,-17 q,+22 q 11.21-q 12.1\end{array}$ & 16 & Homozygous deletion 2 \\
\hline D250 & Ewing & PRI & $-3 q|3.3|-q 22.3$, del $9 p 21.3,-X p|| .3$ & 3 & Homozygous deletion 2 \\
\hline D3II & Ewing & PRI & $\begin{array}{l}+\mid q 22-q \text { ter, +8, - I0p 15.3, -16q, +|7q21.31-qter, - } \\
19 q \mid 3.43\end{array}$ & 6 & No deletion 3 \\
\hline D313 & Ewing & PRI & $+2,+8$ & 2 & No deletion 3 \\
\hline D316 & Ewing & PRI & $\begin{array}{l}+2,+8,+|4 q||.2-q| 3.2,-|4 q| 3.3-q 2|.|,+|4 q 2| . \mid- \\
q t e r,-X\end{array}$ & 6 & No deletion 3 \\
\hline D320 & Ewing & PRI & +8 & 1 & No deletion 3 \\
\hline D322 & Ewing & PRI & $+8,-16 q,+19 p$ & 3 & No deletion 3 \\
\hline D242 & Ewing Extr & PRI & +19 & 1 & No deletion 2 \\
\hline D246 & Ewing Extr & PRI & No changes detected & 0 & No deletion 2 \\
\hline D249 & Ewing Extr & PRI & 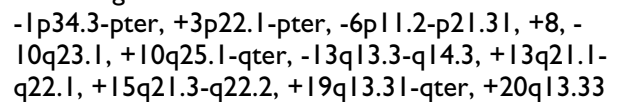 & II & No deletion 2 \\
\hline D252 & Ewing Extr & PRI & $+2,+5,+6,-7,+8,-9 \mathrm{p} 21.3,+12,+14,+21,-X$ & 10 & Homozygous deletion 2 \\
\hline D253 & Askin's & PRI & $+8,-Y$ & 2 & No deletion 2 \\
\hline D254 & Askin's & PRI & $\begin{array}{l}+2,+3,-4 q 34.3-q t e r,-5,+6,-7,-9, \text { del } 9 p 21.3,-10 \\
+1 \mid q 24.3-q \text { ter, }+12,-13,+14,+16,+18,+19,+20 \\
+21,+22 q \mid 1.21-q 12.1\end{array}$ & 19 & Homozygous deletion 2 \\
\hline DI57 & Ewing & REC & $\begin{array}{l}+2 p,+2 q|1.2-q 22.3,-3 q| 3.13-q 13.33,+4 q 31.3- \\
q t e r,+8,+12 p,+|2 q| 2-q 21.3 \mid,-16 q,-17 p,-19,+X\end{array}$ & 11 & No deletion 2 \\
\hline DI56 & Askin's & REC & $\begin{array}{l}+|q,+8 p||.2|-p|| .22,+8 p 23 . \mid-p t e r,+8 q \\
+|| q|2.3-q| 3.2,+|2 q| 3.2-q|4 .|,-|6 q,+| 9 p\end{array}$ & 8 & No deletion 2 \\
\hline D255 & Ewing & MET & $\begin{array}{l}+19,+2,+5,+6,+8,+12,+13,+15,-16,-17,+18,- \\
19,+20,+21\end{array}$ & 14 & No deletion 2 \\
\hline D256 & Ewing & MET & - Iq $24.2-q 25.3,+8$ & 2 & No deletion 3 \\
\hline D312 & Ewing & MET & $\begin{array}{l}+1,+2 p,+2 q \mid 1.2-q 21.3,-3,-4,-5 q,+6 p,+6 q 12,- \\
6 q|3-q t e r,+7 q,+8,+9,-10,-1| p,-1|q| 2.1-q 24.2 \\
+1|q 24.3-q t e r,+12,-13,+14,+15 q| 5.2-q t e r,-16 q \\
-17,-18,-19,+20,+X\end{array}$ & 26 & No deletion 3 \\
\hline D321 & Ewing & MET & $\begin{array}{l}+2,+5,+6,+8,+|4,+| 5,-16 q,-20 p,+21,- \\
\text { Xp|I.2I-p||.22, -Xq }\end{array}$ & 11 & No deletion 3 \\
\hline D257 & PNET & MET & $\begin{array}{l}+|p| 1.2-p|3.2,+| p 22.1-p 32.3,+I p 35.1-p t e r,+I q,- \\
3 p 24.3-p 25.1,+6 q 23.1-q \text { - } \\
q 33.3,+|2 p,+| 2 q|2-q| 5\end{array}$ & 12 & Heterozygous deletion 2 \\
\hline D3।5 & PNET & MET & $\begin{array}{l}-7 p,-9 p 21.1-p 21.3 \text {, del 9p21.3, -16q, -22q12.1, - } \\
22 q \mid 3.2-q 13.32\end{array}$ & 6 & Homozygous deletion 3 \\
\hline
\end{tabular}

ICDKN2A deletion was regarded as homozygous if the copy number $\log _{2}$ ratio was $<-2.0$ and as heterozygous if the ratio was -1.5 to $-2.0 .{ }^{2} C D K N 2 A$ deletion result published previously by Savola et al. [18] in an article, which included total of 26 ESFT patient samples. ${ }^{3} C D K N 2 A$ deletion status not published before.

Extr = extraskeletal; PRI = primary tumor; REC = local recurrence; $M E T$ = metastasis. 
Table 3: Putative target genes for tumorigenesis and tumor progression in recurrent copy number changes of the 16 ESFT patients included in the integration analysis.

\begin{tabular}{|c|c|c|c|c|c|c|c|c|}
\hline Symbol & Name & Cytoband & Location' & Correlation & p-value & $\begin{array}{l}\text { Copy number } \\
\text { status }^{2}\end{array}$ & q-value & $\begin{array}{l}\text { Functional } \\
\text { information }\end{array}$ \\
\hline HEATR3 & $\begin{array}{l}\text { HEAT repeat } \\
\text { containing } 3\end{array}$ & $16 q \mid 2.1$ & $\begin{array}{l}48697286- \\
48697733\end{array}$ & 0,876 & $2,2 \mathrm{E}-16$ & Deleted & $6,05 \mathrm{E}-13$ & NA \\
\hline TRAFDI & $\begin{array}{l}\text { TRAF-type zinc } \\
\text { finger domain } \\
\text { containing I }\end{array}$ & $12 q 24.12$ & $\begin{array}{l}111075038- \\
111075556\end{array}$ & 0,853 & $2,2 \mathrm{E}-16$ & Gained & $6,05 \mathrm{E}-13$ & {$[47]$} \\
\hline Clorfl3I & $\begin{array}{l}\text { Chromosome I } \\
\text { open reading frame } \\
|3|\end{array}$ & Iq42.2 & $\begin{array}{l}229426179- \\
229426672\end{array}$ & 0,850 & $2,2 \mathrm{E}-16$ & Unspecified & $6,05 \mathrm{E}-13$ & NA \\
\hline HDGF & $\begin{array}{l}\text { Hepatoma-derived } \\
\text { growth factor }\end{array}$ & Iq21-q23 & $\begin{array}{l}\text { I54978607- } \\
\text { |54979|| } 5\end{array}$ & 0,844 & $\mathrm{I}, 5 \mathrm{E}-05$ & Gained & $0,024 \mid 82394$ & {$[34,36-38]$} \\
\hline DDX47 & $\begin{array}{l}\text { DEAD (Asp-Glu-Ala- } \\
\text { Asp) box } \\
\text { polypeptide } 47\end{array}$ & $12 p|3|$. & $\begin{array}{l}\mid 2873623- \\
|2874| 34\end{array}$ & 0,844 & I,5E-05 & Gained & $0,024 \mid 82394$ & {$[48]$} \\
\hline GIGYF2 & $\begin{array}{l}\text { GRB } 10 \text { interacting } \\
\text { GYF protein } 2\end{array}$ & $2 q 37.1$ & $\begin{array}{l}233431003- \\
233431539\end{array}$ & 0,838 & $3,5 \mathrm{E}-05$ & Unspecified & $0,04774 I I 59$ & [49-5I] \\
\hline C2orf49 & $\begin{array}{l}\text { Chromosome } 2 \\
\text { open reading frame } \\
49\end{array}$ & $2 q 12.2$ & $\begin{array}{l}105331075- \\
105331416\end{array}$ & 0,832 & 5,9E-05 & Unspecified & 0,069391132 & NA \\
\hline TMEM63A & $\begin{array}{l}\text { Transmembrane } \\
\text { protein } 63 \mathrm{~A}\end{array}$ & $1 \mathrm{q} 42.12$ & $\begin{array}{l}224110806- \\
224111244\end{array}$ & 0,829 & $7,3 \mathrm{E}-05$ & Gained & $0,0749 \mid 325$ & NA \\
\hline WDR67 & $\begin{array}{l}\text { WD repeat domain } \\
67\end{array}$ & $8 q 24.13$ & $\begin{array}{l}\text { I } 24233227- \\
\text { I } 24233523\end{array}$ & 0,826 & $8,8 \mathrm{E}-05$ & Gained & 0,080319015 & NA \\
\hline GSDMDI & Gasdermin D & $8 q 24.3$ & $\begin{array}{l}\text { |447|0202- } \\
|447| 0602\end{array}$ & $-0,821$ & I,3E-04 & Gained & 0,107927089 & NA \\
\hline GPATCH2 & $\begin{array}{l}\text { G patch domain } \\
\text { containing } 2\end{array}$ & $|q 4|$ & $\begin{array}{l}215848737- \\
215849264\end{array}$ & 0,812 & $\mathrm{I}, 8 \mathrm{E}-04$ & Unspecified & $0,|3737656|$ & NA \\
\hline WSB2 & $\begin{array}{l}\text { WD repeat and } \\
\text { SOCS box- } \\
\text { containing } 2\end{array}$ & $12 q 24.23$ & $\begin{array}{l}116955326- \\
116955682\end{array}$ & 0,809 & $2, \mathrm{IE}-04$ & Unspecified & 0,142275217 & {$[42]$} \\
\hline CACNAIC & $\begin{array}{l}\text { Calcium channel, } \\
\text { voltage-dependent, L } \\
\text { type, alpha IC } \\
\text { subunit }\end{array}$ & $|2 p| 3.3$ & $\begin{array}{l}2670999 \\
2671234\end{array}$ & $-0,803$ & 2,7E-04 & Deleted & 0,160672631 & {$[40,4 I]$} \\
\hline KRT79 & Keratin 79 & $12 q 13.13$ & $\begin{array}{l}51501640 \\
51502010\end{array}$ & $-0,800$ & $3,0 \mathrm{E}-04$ & Unspecified & $0,|6067263|$ & NA \\
\hline PPHLNI & Periphilin I & $12 q \mid 2$ & $\begin{array}{l}41121456- \\
41121979\end{array}$ & 0,797 & $3,2 \mathrm{E}-04$ & Gained & 0,160672631 & {$[43,44]$} \\
\hline Clorflo7 & $\begin{array}{l}\text { Chromosome I } \\
\text { open reading frame } \\
\text { I07 }\end{array}$ & $1 \mathrm{q} 32.2$ & $\begin{array}{l}20809698 I- \\
208097464\end{array}$ & 0,794 & $3,5 \mathrm{E}-04$ & Gained & 0,160672631 & NA \\
\hline$F B X L / 4$ & $\begin{array}{l}\text { F-box and leucine- } \\
\text { rich repeat protein } \\
\text { I4 }\end{array}$ & $|2 p| 3.33$ & $\begin{array}{l}1570852- \\
157 \mid 348\end{array}$ & 0,794 & $3,5 \mathrm{E}-04$ & Unspecified & 0,160672631 & NA \\
\hline ANKRDII & $\begin{array}{l}\text { Ankyrin repeat } \\
\text { domain II }\end{array}$ & $16 q 24.3$ & $\begin{array}{l}87999533- \\
87999771\end{array}$ & 0,794 & $3,5 \mathrm{E}-04$ & Deleted & 0,160672631 & {$[45,52]$} \\
\hline HEATRI & $\begin{array}{l}\text { HEAT repeat } \\
\text { containing I }\end{array}$ & Iq43 & $\begin{array}{l}2348 \mid 5741- \\
234816376\end{array}$ & 0,791 & $3,9 \mathrm{E}-04$ & Gained & $0,16067263 \mid$ & NA \\
\hline COG2 & $\begin{array}{l}\text { Component of } \\
\text { oligomeric golgi } \\
\text { complex } 2\end{array}$ & Iq42.2 & $\begin{array}{l}228895774- \\
228896323\end{array}$ & 0,791 & $3,9 \mathrm{E}-04$ & Gained & 0,160672631 & [39] \\
\hline
\end{tabular}

'Location of the Affymetrix target sequence using BLAST algorithm. ${ }^{2}$ Copy number status $=$ characterization of the copy number status in the whole patient set; unspecified indicates that both amplifications and deletions were found. NA = not available.

sive course of disease [27]. Unfortunately our sample set was not large enough in statistical power to study this aspect.
Interestingly, sample D154, which was negative for EWSFLI1 translocation types that we tested, showed cryptic amplifications on chromosomes 20 and 22 (Figs. 3E and $3 F)$. Szuhai et al. have reported a similar case with $20 \mathrm{q}$ and $22 \mathrm{q}$ amplifications, suggesting that the translocation 
A)

B)

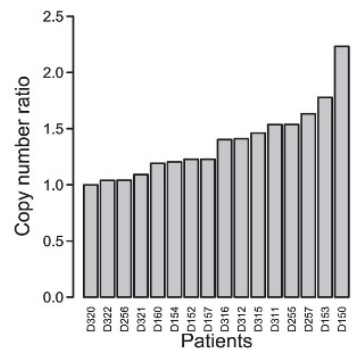

C)
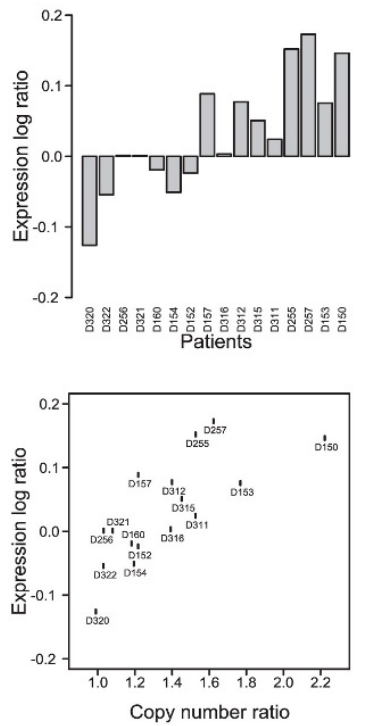

D)

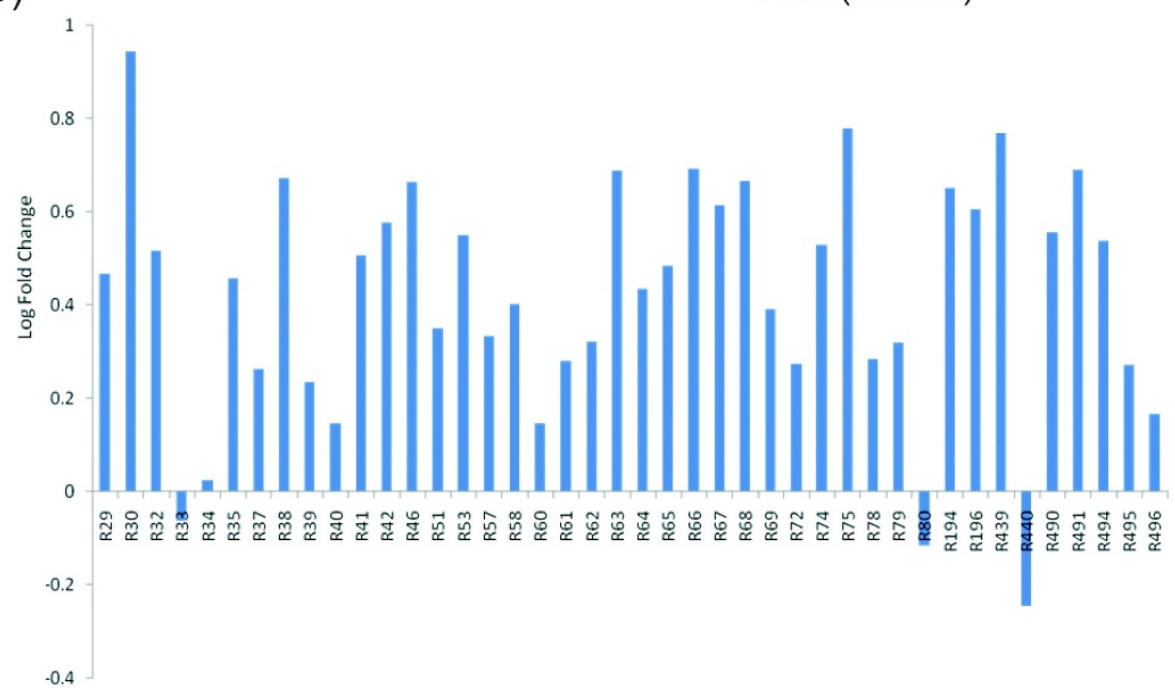

Figure 4

Correlation of HDGF copy number and expression by microarray analysis and validation of HDGF expression using RT-PCR. A) HDGF copy number ratio and B) HDGF expression ratio by microarray analysis in ESFT patient samples (n $=16$ ). The patients in figure $A$ ) and $B$ ) are in the same order, and labelled according to the codes of the DNA samples. C) Correlation of HDGF copy number and expression ratio (correlation 0.844, $\mathrm{P}<0.00 \mathrm{I}$, q-value 0.024 ). D) HDGF expression in ESFT patient samples $(n=42)$ by RT-PCR analysis, on $y$-axis refers to log of fold-change in HDGF gene expression and x-axis to patients RNA code number. Kaplan-Meier plots of ESFT patient $(n=42)$ survival according to D) event-free survival and E) overall survival, patients with high expression of HDGF in bold line and patients with low expression in hatched line. 
partner of EWSR1 is at 20q [28]. However, the specific chromosomal region in $20 \mathrm{q}$ remained unknown. Based on our results, the translocation partner of EWSR1 on chromosome 20 might reside in the amplification breakpoint, either at 20q11.23 or 20q13.12-q13.2 (Fig. 2E). Putative translocation partners of EWSR1 are therefore genes assigned to the breakpoints of these amplifications:RPN2, BLCAP, CDH22, SLC13A3, EYA2, NCOA3, $K u a-U E V$, and NFATC2. Based on literature, the most interesting candidates are EYA2 (located at 20q13.12), which has been found to function as a transcriptional activator in ovarian cancer cells [29], and NFATC2 (located at 20q13.2), which functions in positive regulation of transcription [30]. Both EYA2 and NFATC2 are oriented on the amplification breakpoints so that they are in the correct direction for transcription after the possible fusion event. In addition to the chromosome 20, genes on region $8 \mathrm{p}$ are interesting as putative fusion partners, since many of these genes are involved in carcinomas and sarcomas. Indeed the region of 8p11.21-p21.2 was gained in patent sample D154. However, the possible involvement of 8p11.21-p21.2 as a location of the translocation partner for EWSR1 was ruled out since this region was not amplified like EWSR1 was. We would assume that the fusion partners would be amplified on the same scale, since translocation is likely to take place before the amplification of the fusion gene.

According to our integrated analysis of array CGH and expression data including 16 ESFT patient samples, we selected as one of the most interesting putative target genes within the common 1q22-qter gain gene HDGF, which has been reported as a putative prognostic marker for several tumor types, e.g., gastrointestinal stromal tumors (GIST) [31,32], hepatocellular carcinoma [33], non-small-cell lung carcinoma [34,35] and pancreatic ductal carcinoma [36]. HDGF has been shown to stimulate cell proliferation and growth after nuclear translocation $[37,38]$, which makes it a likely target also in ESFT. Furthermore, our preliminary results from an aCGH analysis of ESFT cell lines showed that HDGF was inside the minimal common overlapping area of 1q21.1-q23.1 (Savola et al, unpublished results). Our RT-PCR analysis confirmed that Ewing's sarcoma cells expressed higher levels of HDGF with respect to putative normal controls (CD34 positive cells and normal muscle tissues). However, when we analyzed HDGF expression level correlation with patient survival, no significant association was seen. So HDGF can play a role in the tumorigenesis and tumor progression of EFST, but it shows no prognostic value. However, due to limitations in numbers of patients ( $n=42$ ) included in the HDGF expression study, no definitive conclusions of the outcome evaluation of HDGF expression in ESFT can be drawn.
Other interesting target genes pinpointed by integration analysis in 1q include TMEM63A (1q42.12), C1orf107 (1q32.2), HEATR1 (1q43), all relatively unknown genes in their functions and COG2 (1q42.2), gene involved in various Golgi functions [39]. In chromosome 8 genes WDR67 (8q24.13) and GSDMDC1 (8q24.3) locating nearby each other and in chromosome 12 DDX47 (12p13.1) and CACNA1C (12p13.3) [40,41] are interesting targets for further studies. Also potential oncogenes in ESFT at $12 \mathrm{q}$ are WSB2 (12q24.23), which takes part in the intracellular signalling cascades and has shown to be a potential biomarker in colorectal cancer [42], PPHLN1 (12q12), which controls cell cycle regulation by modifying expression of cdc7 involved in progression of DNA replication $[43,44]$ and KRT79 (12q13.13), a member of human type II keratin gene family. Previously loss of $16 \mathrm{q}$ has been shown to be a sign of poor prognosis in ESFT $[7,13]$. Our results suggest that the putative target gene within this chromosomal area is HEATR3 (16q12.1) or ANKRD11 (16q24.3), which has been recently identified to interact with p53 and act as a co-activator in the regulatory feedback loop with p53 [45]. Functional studies to confirm these results are warranted.

\section{Conclusion}

This study adds new information regarding gene copy number changes and their relation to expression in ESFT providing valuable data for further analysis. In addition, array CGH showed to be efficient in the detection of a putative novel translocation in one patient sample and provided new information about copy number changes of the EWS/FLI1 fusion gene. Therefore we can conclude that array CGH analysis and integrated DNA microarray analysis of global gene expression patterns and gene copy number imbalances is a powerful method to identify novel molecular targets and chromosomal regions of highest interest in ESFT.

\section{Competing interests}

The authors declare that they have no competing interests.

\section{Authors' contributions}

SS designed the study plan, carried out array analysis, interpreted the data and wrote the manuscript. AK and AT performed bioinformatic analysis in the supervision and coordination of SKaski. TN took part in the array CGH analysis. MS, PP, DZ and KS provided clinical specimens, collected the clinical data, performed and organized HDGF analysis by RT-PCR and contributed to the design of study plan. SKnuutila was the principal investigator managing the conception of the study and data interpretation. All authors contributed to the manuscript and approved the final version of it. 


\section{Additional material}

\section{Additional file 1}

Results of integration analysis on RNA and DNA data in ESFT. Complete results of bioinformatic analysis (gene location, correlation, p-value, $q$-value and copy number status) on DNA and RNA data integration. Click here for file

[http://www.biomedcentral.com/content/supplementary/14712407-9-17-S1.xls]

\section{Additional file 2}

Clinical data summary of 42 ESFT patients in HDGF expression and survival analysis. Table of clinical characteristics (sex, age, location of tumor, event-free and over all survival) of ESFT patients studied in RTPCR analysis of HDGF.

Click here for file

[http://www.biomedcentral.com/content/supplementary/14712407-9-17-S2.doc]

\section{Acknowledgements}

This study was supported by grants from European Commission (PROTHETS LSHC-CT-503036 and EuroBoNeT LSHC-CT-2006-0I88I4), AIRC (Italian Association for Cancer Research), Finnish Cultural Foundation and Academy of Finland (SYSBIO research programme). The authors wish to acknowledge the excellent technical assistance of Filippo Nardi and the precious help of Lara Cantiani.

\section{References}

I. Delattre O, Zucman J, Plougastel B, Desmaze C, Melot T, Peter M, Kovar H, Joubert I, de Jong P, Rouleau G: Gene fusion with an ETS DNA-binding domain caused by chromosome translocation in human tumours. Nature 1992, 359(6391):162-165.

2. Burchill SA: Ewing's sarcoma: diagnostic, prognostic, and therapeutic implications of molecular abnormalities. J Clin Pathol 2003, 56(2):96-102.

3. Herzog CE: Overview of sarcomas in the adolescent and young adult population. J Pediatr Hematol Oncol 2005, 27(4):215-218.

4. Armengol G, Tarkkanen M, Virolainen M, Forus A, Valle J, Bohling T, Asko-Seljavaara S, Blomqvist C, Elomaa I, Karaharju E, Kivioja AH, Siimes MA, Tukiainen E, Caballin MR, Myklebost O, Knuutila S: Recurrent gains of Iq, 8 and 12 in the Ewing family of tumours by comparative genomic hybridization. $\mathrm{Br} J$ Cancer 1997, 75( I 0): | 403-1409.

5. Tarkkanen M, Kiuru-Kuhlefelt S, Blomqvist C, Armengol G, Bohling T, Ekfors T, Virolainen M, Lindholm P, Monge O, Picci P, Knuutila S, Elomaa I: Clinical correlations of genetic changes by comparative genomic hybridization in Ewing sarcoma and related tumors. Cancer Genet Cytogenet I 999, I I 4(I):35-4I.

6. Brisset S, Schleiermacher G, Peter M, Mairal A, Oberlin O, Delattre $O$, Aurias $A: \mathbf{C G H}$ analysis of secondary genetic changes in Ewing tumors: correlation with metastatic disease in a series of 43 cases. Cancer Genet Cytogenet 200 I, I 30(I):57-6I.

7. Ozaki T, Paulussen M, Poremba C, Brinkschmidt C, Rerin J, Ahrens S, Hoffmann C, Hillmann A, Wai D, Schaefer KL, Boecker W, Juergens $H$, Winkelmann W, Dockhorn-Dworniczak B: Genetic imbalances revealed by comparative genomic hybridization in Ewing tumors. Genes Chromosomes Cancer 2001, 32(2): 164-171.

8. Amiel A, Ohali A, Fejgin M, Sardos-Albertini F, Bouaron N, Cohen IJ, Yaniv I, Zaizov R, Avigad S: Molecular cytogenetic parameters in Ewing sarcoma. Cancer Genet Cytogenet 2003, I40(2): 107-I I 2.

9. Ferreira BI, Alonso J, Carrillo J, Acquadro F, Largo C, Suela J, Teixeira MR, Cerveira N, Molares A, Gomez-Lopez G, Pestana A, Sastre A, Garcia-Miguel P, Cigudosa JC: Array CGH and gene-expression profiling reveals distinct genomic instability patterns associ- ated with DNA repair and cell-cycle checkpoint pathways in Ewing's sarcoma. Oncogene 2007, 27(14):2084-90.

10. Sandberg AA, Bridge JA: Updates on cytogenetics and molecular genetics of bone and soft tissue tumors: Ewing sarcoma and peripheral primitive neuroectodermal tumors. Cancer Genet Cytogenet 2000, I 23(I): I-26.

II. Zielenska M, Zhang ZM, Ng K, Marrano P, Bayani J, Ramirez OC, Sorensen P, Thorner P, Greenberg M, Squire JA: Acquisition of secondary structural chromosomal changes in pediatric ewing sarcoma is a probable prognostic factor for tumor response and clinical outcome. Cancer 200I, 9 I(II):2156-2I64.

12. Hattinger CM, Rumpler S, Strehl S, Ambros IM, Zoubek A, Potschger $\mathrm{U}$, Gadner H, Ambros PF: Prognostic impact of deletions at Ip36 and numerical aberrations in Ewing tumors. Genes Chromosomes Cancer 1999, 24(3):243-254.

13. Hattinger CM, Potschger U, Tarkkanen M, Squire J, Zielenska M, Kiuru-Kuhlefelt S, Kager L, Thorner P, Knuutila S, Niggli FK, Ambros PF, Gadner H, Betts DR: Prognostic impact of chromosomal aberrations in Ewing tumours. $\mathrm{Br} J$ Cancer 2002, 86(II): $1763-1769$

14. Huang HY, Illei PB, Zhao Z, Mazumdar M, Huvos AG, Healey JH, Wexler LH, Gorlick R, Meyers P, Ladanyi M: Ewing sarcomas with p53 mutation or p I6/p I 4ARF homozygous deletion: a highly lethal subset associated with poor chemoresponse. J Clin Oncol 2005, 23(3):548-558.

15. Rosito P, Mancini AF, Rondelli R, Abate ME, Pession A, Bedei L, Bacci G, Picci P, Mercuri M, Ruggieri P, Frezza G, Campanacci M, Paolucci G: Italian Cooperative Study for the treatment of children and young adults with localized Ewing sarcoma of bone: a preliminary report of 6 years of experience. Cancer 1999, 86(3):42I-428.

16. Bacci G, Balladelli A, Forni C, Ferrari S, Longhi A, Benassi MS, Briccoli A, Serra M, Picci P: Adjuvant and neo-adjuvant chemotherapy for Ewing's sarcoma family tumors and osteosarcoma of the extremity: further outcome for patients event-free survivors 5 years from the beginning of treatment. Ann Oncol 2007, I 8( I 2):2037-2040.

17. Scheinin I, Myllykangas S, Borze I, Bohling T, Knuutila S, Saharinen J: CanGEM: mining gene copy number changes in cancer. Nucleic Acids Res 2008:D830-5.

18. Savola S, Nardi F, Scotlandi K, Picci P, Knuutila S: Microdeletions in 9p2I.3 induce false negative results in CDKN2A FISH analysis of Ewing sarcoma. Cytogenet Genome Res 2007, II9(I2):21-26.

19. Usvasalo A, Savola S, Raty R, Vettenranta K, Harila-Saari A, Koistinen $P$, Savolainen ER, Elonen E, Saarinen-Pihkala UM, Knuutila S: CDKN2A deletions in acute lymphoblastic leukemia of adolescents and young adults-An array CGH study. Leuk Res 2008, 32(8): $1228-35$.

20. Myllykangas S, Junnila S, Kokkola A, Autio R, Scheinin I, Kiviluoto T, Karjalainen-Lindsberg ML, Hollmen J, Knuutila S, Puolakkainen P, Monni $O$ : Integrated gene copy number and expression microarray analysis of gastric cancer highlights potential target genes. Int J Cancer 2008, I 23(4):817-825.

21. Best DJ, Roberts DE: Algorithm AS 89: The Upper Tail Probabilities of Spearman's rho. Applied Statistics 1975, 24(3):377-379.

22. Storey JD, Tibshirani R: Statistical significance for genomewide studies. Proc Natl Acad Sci USA 2003, I 00( I6):9440-9445.

23. Livak KJ, Schmittgen TD: Analysis of relative gene expression data using real-time quantitative PCR and the 2(-Delta Delta C(T)) Method. Methods 200I, 25(4):402-408.

24. Udayakumar AM, Sundareshan TS: Cytogenetic characterization of Ewing tumors: further update on 20 cases. Cancer Genet Cytogenet 2002, I33(I): 102-103.

25. Weber-Hall S, McManus A, Anderson J, Nojima T, Abe S, PritchardJones K, Shipley J: Novel formation and amplification of the PAX7-FKHR fusion gene in a case of alveolar rhabdomyosarcoma. Genes Chromosomes Cancer 1996, I7(I):7-13.

26. Sirvent N, Maire G, Pedeutour F: Genetics of dermatofibrosarcoma protuberans family of tumors: from ring chromosomes to tyrosine kinase inhibitor treatment. Genes Chromosomes Cancer 2003, 37(I): I- 19.

27. Graux C, Cools J, Melotte C, Quentmeier H, Ferrando A, Levine R, Vermeesch JR, Stul M, Dutta B, Boeckx N, Bosly A, Heimann P, Uyttebroeck A, Mentens N, Somers R, MacLeod RA, Drexler HG, Look AT, Gilliland DG, Michaux L, Vandenberghe P, Wlodarska I, Marynen 
P, Hagemeijer A: Fusion of NUP2 I 4 to ABLI on amplified episomes in T-cell acute lymphoblastic leukemia. Nat Genet 2004, 36(10): 1084-1089.

28. Szuhai K, IJszenga M, Tanke HJ, Taminiau AH, de Schepper A, van Duinen SG, Rosenberg C, Hogendoorn PC: Detection and molecular cytogenetic characterization of a novel ring chromosome in a histological variant of Ewing sarcoma. Cancer Genet Cytogenet 2007, 172(1):12-22.

29. Zhang L, Yang N, Huang J, Buckanovich RJ, Liang S, Barchetti A, Vezzani C, O'Brien-Jenkins A, Wang J, Ward MR, Courreges MC, Fracchioli S, Medina A, Katsaros D, Weber BL, Coukos G: Transcriptional coactivator Drosophila eyes absent homologue $\mathbf{2}$ is up-regulated in epithelial ovarian cancer and promotes tumor growth. Cancer Res 2005, 65(3):925-932.

30. Bettelli $E$, Dastrange M, Oukka M: Foxp3 interacts with nuclear factor of activated $T$ cells and NF-kappa B to repress cytokine gene expression and effector functions of $\mathrm{T}$ helper cells. Proc Natl Acad Sci USA 2005, I 22(I 4):5 I 38-5 I 43.

31. Yamamoto S, Tomita Y, Hoshida Y, Takiguchi S, Fujiwara Y, Yasuda T, Doki Y, Yoshida K, Aozasa K, Nakamura H, Monden M: Expression of hepatoma-derived growth factor is correlated with lymph node metastasis and prognosis of gastric carcinoma. Clin Cancer Res 2006, I 2(I): I 17-122.

32. Chang KC, Tai MH, Lin JW, Wang CC, Huang CC, Hung $\mathrm{CH}$, Chen $\mathrm{CH}$, Lu SN, Lee CM, Changchien CS, Hu TH: Hepatoma-derived growth factor is a novel prognostic factor for gastrointestinal stromal tumors. Int J Cancer 2007, I 2 I (5): 1059-1065.

33. Yoshida K, Tomita $Y$, Okuda $Y$, Yamamoto S, Enomoto H, Uyama $\mathrm{H}$, Ito H, Hoshida Y, Aozasa K, Nagano H, Sakon M, Kawase I, Monden $M$, Nakamura $\mathrm{H}$ : Hepatoma-derived growth factor is a novel prognostic factor for hepatocellular carcinoma. Ann Surg Oncol 2006, 13(2):159-167.

34. Ren H, Tang X, Lee J], Feng L, Everett AD, Hong WK, Khuri FR, Mao $\mathrm{L}$ : Expression of hepatoma-derived growth factor is a strong prognostic predictor for patients with early-stage non-smallcell lung cancer. J Clin Oncol 2004, 22(16):3230-3237.

35. Iwasaki T, Nakagawa K, Nakamura H, Takada Y, Matsui K, Kawahara $\mathrm{K}$ : Hepatoma-derived growth factor as a prognostic marker in completely resected non-small-cell lung cancer. Oncol Rep 2005, I3(6): 1075-1080.

36. Uyama $\mathrm{H}$, Tomita $\mathrm{Y}$, Nakamura $\mathrm{H}$, Nakamori S, Zhang B, Hoshida $\mathrm{Y}$, Enomoto H, Okuda Y, Sakon M, Aozasa K, Kawase I, Hayashi N, Monden M: Hepatoma-derived growth factor is a novel prognostic factor for patients with pancreatic cancer. Clin Cancer Res 2006, I 2(20 Pt I):6043-6048.

37. Everett AD, Stoops T, McNamara CA: Nuclear targeting is required for hepatoma-derived growth factor-stimulated mitogenesis in vascular smooth muscle cells. J Biol Chem 200I, 276(40):37564-37568.

38. Kishima $Y$, Yamamoto $H$, Izumoto $Y$, Yoshida $\mathrm{K}$, Enomoto $\mathrm{H}$, Yamamoto M, Kuroda T, Ito H, Yoshizaki K, Nakamura $H$ : Hepatoma-derived growth factor stimulates cell growth after translocation to the nucleus by nuclear localization signals. J Biol Chem 2002, 277(1 2): 10315-10322.

39. Sohda M, Misumi Y, Yoshimura S, Nakamura N, Fusano T, Ogata S, Sakisaka $S$, Ikehara $Y$ : The interaction of two tethering factors, pII 5 and COG complex, is required for Golgi integrity. Traffic 2007, 8(3):270-284.

40. Sun W, McPherson JD, Hoang DQ, Wasmuth J], Evans GA, Montal M: Mapping of a human brain voltage-gated calcium channel to human chromosome 12p/3-pter. Genomics 1992, 14(4): 1092-1094.

4I. Zahanich I, Graf EM, Heubach JF, Hempel U, Boxberger S, Ravens U: Molecular and functional expression of voltage-operated calcium channels during osteogenic differentiation of human mesenchymal stem cells. J Bone Miner Res 2005, 20(9):1637-1646.

42. Li XG, Song JD, Wang YQ: Differential expression of a novel colorectal cancer differentiation-related gene in colorectal cancer. World J Gastroenterol 200I, 7(4):55I-554.

43. Kazerounian S, Aho S: Characterization of periphilin, a widespread, highly insoluble nuclear protein and potential constituent of the keratinocyte cornified envelope. I Biol Chem 2003, 278(38):36707-367।17.

44. Kurita M, Suzuki H, Masai H, Mizumoto K, Ogata E, Nishimoto I, Aiso S, Matsuoka M: Overexpression of CR/periphilin downregu- lates Cdc7 expression and induces S-phase arrest. Biochem Biophys Res Commun 2004, 324(2):554-56I.

45. Neilsen PM, Cheney KM, Li CW, Chen JD, Cawrse JE, Schulz RB, Powell JA, Kumar R, Callen DF: Identification of ANKRDI I as a p53 coactivator. J Cell Sci 2008, I 2 I (Pt 2 I):354I-3552.

46. Baudis M, Cleary ML: Progenetix.net: an online repository for molecular cytogenetic aberration data. Bioinformatics 200I, I7( I 2): I228-I229.

47. Mashima R, Saeki K, Aki D, Minoda Y, Takaki H, Sanada T, Kobayashi T, Aburatani H, Yamanashi Y, Yoshimura A: FLN29, a novel interferon- and LPS-inducible gene acting as a negative regulator of toll-like receptor signaling. I Biol Chem 2005, 280(50):4I 289-4I 297

48. Lee JH, Rho SB, Chun T: GABAA receptor-associated protein (GABARAP) induces apoptosis by interacting with DEAD (Asp-Glu-Ala-Asp/His) box polypeptide 47 (DDX 47). Biotechnol Lett 2005, 27(9):623-628.

49. Giovannone B, Lee E, Laviola L, Giorgino F, Cleveland KA, Smith RJ: Two novel proteins that are linked to insulin-like growth factor (IGF-I) receptors by the Grblo adapter and modulate IGF-I signaling. J Biol Chem 2003, 278(34):3। 564-3I 573.

50. Lautier C, Goldwurm S, Durr A, Giovannone B, Tsiaras WG, Pezzoli G, Brice A, Smith RJ: Mutations in the GIGYF2 (TNRCI 5) gene at the PARKI I locus in familial Parkinson disease. Am J Hum Genet 2008, 82(4):822-833.

5I. Bras J, Simon-Sanchez J, Federoff M, Morgadinho A, Januario C Ribeiro M, Cunha L, Oliveira C, Singleton AB: Lack of replication of association between GIGYF2 variants and Parkinson disease. Hum Mol Genet 2008 in press.

52. Zhang A, Li CW, Chen JD: Characterization of transcriptional regulatory domains of ankyrin repeat cofactor-I. Biochem Biophys Res Commun 2007, 358(4): $1034-1040$.

\section{Pre-publication history}

The pre-publication history for this paper can be accessed here:

http://www.biomedcentral.com/1471-2407/9/17/prepub

Publish with BioMed Central and every scientist can read your work free of charge

"BioMed Central will be the most significant development for disseminating the results of biomedical research in our lifetime."

Sir Paul Nurse, Cancer Research UK

Your research papers will be:

- available free of charge to the entire biomedical community

- peer reviewed and published immediately upon acceptance

- cited in PubMed and archived on PubMed Central

- yours - you keep the copyright
BioMedcentral 